\title{
Germany gives green light to gene patents
}

Quirin Schiermeier, Munich

The German cabinet last week endorsed the patenting of human genes, when it approved a European Union (EU) directive on the legal protection of biotechnological inventions.

The move is a significant step towards the directive's adoption across Europe. It was approved at the European level in 1998 after almost ten years of preparation, and is intended to harmonize biotechnology patents in the EU (see Nature 388, 314; 1997). But ethicists and scientists still object to some clauses - albeit on different grounds.

Controversy surrounds a clause stating that patents can be granted on an "element isolated from the human body or otherwise produced by means of a technical process ... even if the structure of that element is identical to that of a natural element". The clause says that such elements can include "the sequence or partial sequence of a gene".

Some say this violates the human right to freedom and protection of the body from ownership. The Netherlands has filed a complaint against the directive at the European Court of Justice on these grounds.

"In its current form [the directive] would lead inexorably to the commercialization of genetic knowledge," says Jean-François Mattei, a Marseilles-based geneticist and member of the French parliament. Mattei will submit a petition calling for a moratorium to President Jacques Chirac next month.

Although EU members are legally obliged to adopt the directive and, where necessary, adapt their legislation to fit it, France and several other member states have yet to

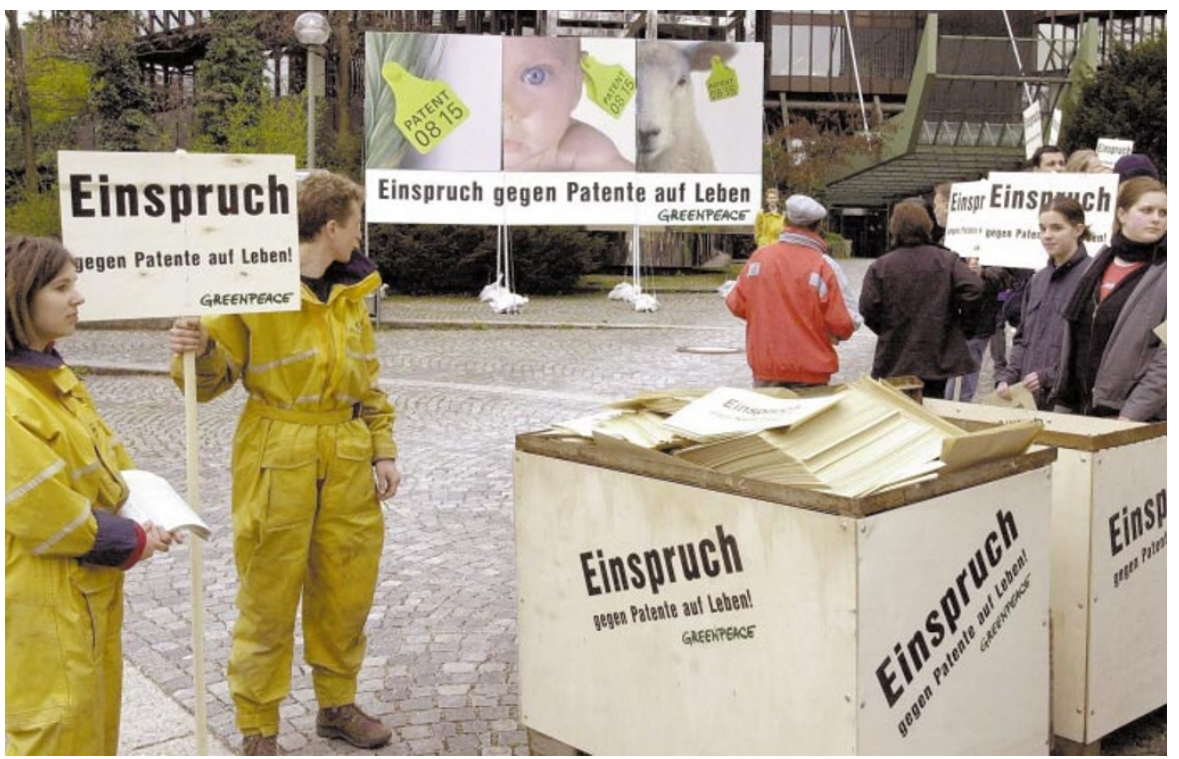

Patent protest: Greenpeace have been orchestrating German objections to the patent law revisions.

do so. Those that have include Denmark, the Republic of Ireland, Finland and Britain.

Discussion is particularly heated in France, because the directive goes against its national patent laws. These state that "the human body, its parts and products, and knowledge of entire or partial structure of the gene as such" cannot be patented.

Many scientists' concerns centre on the breadth of gene patents. Some have warned that the development of drugs and therapies could be blocked, or prices increased, if gene patents could cover all possible functions of a sequence (see Nature 406, 111;2000).

\section{Human Frontier repatriation boost}

Researchers awarded postdoctoral fellowships under the Human Frontier Science Program (HFSP) to study abroad are to get financial incentives to return home when the grant expires. The move reflects concern that a significant proportion are staying in the country that they have visited - particularly the United States.

HFSP fellowships are to be extended from two to three years, and grant-holders will be able to spend the third year back home. The HFSP has also proposed the creation of a new career development award. This would allow repatriated fellows to apply for a two-year extension to their fellowship, including US\$50,000 to build up an independent research group at home.

The HFSP was set up in 1989 to improve international collaboration in molecular biology and neuroscience. It now has a

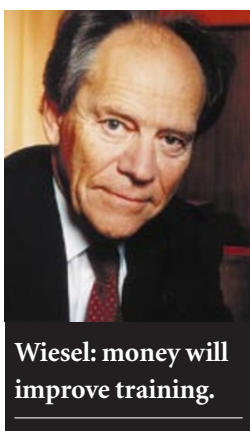

budget of about $\$ 50$ million per year. But $70 \%$ of HFSP fellows who move to the United States remain there after completing their fellowship (see Nature 399, 398; 1999). Under the proposed new scheme, the number of fellowships awarded each year would fall by one-third, to 110 . But Torsten Wiesel, secretary-general of the HFSP and president emeritus of the Rockefeller University in New York, hopes that the new rules will improve HFSP fellows' training by giving them more time to adapt to a foreign environment and new equîp improve the repatriation rate of fellows. Q.S.
The ministerial comments accompanying the German bill, which are intended to guide its implementation, address this concern. They say that the German and European patent offices should "restrict a patent to those parts of a gene substantial for the function described in the application".

Applicants would need to give a concrete description of the function of a gene, and protection would generally be awarded on smaller sequences. This would minimize cases where additional patentable functions are assigned to already protected gene sequences.

But Axel Kahn, director of the INSERM Laboratory of Research on Genetics and Molecular Pathology at the Cochin Institute of Molecular Genetics in Paris, doubts that national comments will solve the problem.

"I regret that the directive contains no unambiguous clause saying that the use of DNA sequences for everything that was not initially described remains free," he says. Kahn points out that there is no reason for the European Patent Office to follow the guidelines in the German law.

But Joseph Straus, head of the department for European patent law at the Max Planck Institute for Foreign and International Patent, Copyright and Competition Law in Munich, is confident that European patent offices will respect the research community's desire for narrow gene patents.

The biotechnology industry in Germany and abroad has welcomed the government's decision. "Those European governments that have agreed on the directive are now reluctant to adopt it," says Bo Hammer Jensen, who chairs the intellectual property rights panel at EuropaBio, the association of European bioindustries. "We are happy that Germany has finally decided to take it on." 